\title{
Preparation, Characterization and Application of Nano Cobalt Aluminates and Cobalt Magnesium Aluminates Blue Pigments
}

\author{
Nehad Hamdy ${ }^{1}$, Abdel-Sattar S. H. Elgazwy ${ }^{2}$, Wagiha H. Mahmoud ${ }^{2}$ and Mohamed M. Selim ${ }^{3 *}$ \\ ${ }^{1}$ Chemistry Administration, Ramsis, Cairo, Egypt \\ ${ }^{2}$ Chemistry Department, Faculty of Science, Ain Shams University, Cairo, Egypt \\ ${ }^{3}$ Physical Chemistry Laboratory, National Research Center, Dokki, Giza, Egypt
}

\section{A R T I C L E I N F O}

Article history:

Received 05 August 2012

Accepted 04 November 2012

Keywords:

Spinel;

Cobalt;

Pigments;

Coating.

\begin{abstract}
A B S T R A C T
Using ceramic and sol gel methods, blue nano cobalt-alumina pigments with spinel structure were prepared. Magnesium was also added to produce another series of pigments. The obtained pigments were characterized by XRD and TEM. The results revealed that the produced compounds have spinel structure with nano size. The introduction of magnesium in the cobalt spinel pigment yields more lighter colors. These pigments were successfully applied for coating metallic surfaces.
\end{abstract}

\section{Introduction}

The particular surface effect, volume effect and quantum size effect ${ }^{[1-2]}$ become apparent because the ratio of the surface atomicity to the bulk atomicity of nanometer particles increases sharply when the diameter of nanometer particles decreases. Therefore, nano particles have a series of new physical and chemical characteristics, which make them have considerable application prospects in adsorption, optics, catalysis, electricity and magnetism, etc. Searching for a suitable preparation method of nanometer particles and studying the structure and other properties of nanometer materials are among the important issues involved for nanometer science applications. Composite oxides with spinel structure $\left(\mathrm{AB}_{2} \mathrm{O}_{4}\right)$ are important inorganic metalloid materials and are widely used in different fields. They are used not only as heat-resistant pigments that can be applied to color up porcelain and ceramics ${ }^{[3]}$, but also as gas-sensitive materials ${ }^{[4]}$, catalytic materials [5], magnetic materials ${ }^{[6]}$ and wave absorption materials ${ }^{[7]}$. The conventional preparation method of spinel pigments is the solid phase synthesis method under high temperature. The shortfall of this method is that it requires a high calcinatory temperature $\left(1200^{\circ} \mathrm{C}\right)$ which consumes a considerable amount of energy ${ }^{[8]}$. In addition, not only the diameter of pigments obtained is large but also the granularity distribution is non uniform, and the pigment particle is hard, which influence the performance of pigments. In this paper, blue nanometer pigments with spinel structure were prepared by ceramic and sol gel method.

\footnotetext{
* Corresponding author.

E-mail address: mmaselim@yahoo.com
}

The nano particles obtained were characterized by X-ray powder diffraction (XRD), transmission electron microscopy (TEM).

\section{Experimental}

\section{1- Spinel preparation using ceramic method.}

Raw materials $\left(\mathrm{Co}\left(\mathrm{NO}_{3}\right)_{2}\right.$ and $\left.\mathrm{AlCl}_{3}\right)$ were from Merc used as received. The $\left(\mathrm{Co}\left(\mathrm{NO}_{3}\right)_{2}\right.$ and $\left.\mathrm{AlCl}_{3}\right)$ in mol ratio 1:2 mole were mixed and the resulting mixture was heated at $300^{\circ} \mathrm{C}$ for $1 \mathrm{hr}$. till the cessation of fumes, then it grind and heated at $1000^{\circ} \mathrm{C}$ for $3 \mathrm{hrs} . \mathrm{Mg} \mathrm{Cl}_{2}$ was added to the mixture in the proportions $\left(\mathrm{Co}_{\mathrm{x}} \mathrm{Mg}_{1-\mathrm{x}}\right.$ $\mathrm{Al}_{2} \mathrm{O}_{4}$ ), where $\mathrm{x}=0.25,0.5,0.75$. The final produced solids were examined by X-ray powder diffraction (XRD) analysis and transmission electron microscopy (TEM).

\subsection{Spinel application}

The prepared spinels were mixed with suitable alkyd and used for coating the metallic surfaces.

\section{Results and discussion}

Solid-solid interaction between $\left(\mathrm{Co}\left(\mathrm{NO}_{3}\right)_{2}\right.$ and $\left.\mathrm{AlCl}_{3}\right)$ at $1000^{\circ} \mathrm{C}$ for $2 \mathrm{hrs}$., yields a compound with bluish-black color which can be considered as a mixed spinel of $\mathrm{Co}_{3} \mathrm{O}_{4}$ (black) and $\mathrm{CoAl}_{2} \mathrm{O}_{4}$ (blue). This mixture obtained because the two compounds have nearly the same d-spacing on the XR-Diffractogram (Fig. 1). The increase of time of calcination up to 3 hours produced a solid with bright blue color i.e. a complete solid-solid interaction between cobalt and aluminium oxides was attained producing well crystalline cobalt aluminate spinel (Fig. 2). The TEM showed that the particle size of the spinel is in the range (20-100nm) as shown in Fig. 3. 
This means that the thermal treatment for $2 \mathrm{hrs}$. is not sufficient for complete reaction between Cobalt oxide and $\mathrm{Al}_{2} \mathrm{O}_{3}$ to achieve well crystalline spinel $\mathrm{CoAl}_{2} \mathrm{O}_{4}$, while the increase of time of thermal treatment up to $3 \mathrm{hrs}$. at $1000^{\circ} \mathrm{C}$ produced well crystalline cobalt aluminate.
XRD patterns of synthesized cobalt magnesium aluminate spinels are shown in Figs. 4-6. The existence of a peak with $\mathrm{d}=2.4$ confirms the formation of cobalt-magnesium aluminate. Separate $\mathrm{MgO}$ crystalline phase was also observed.

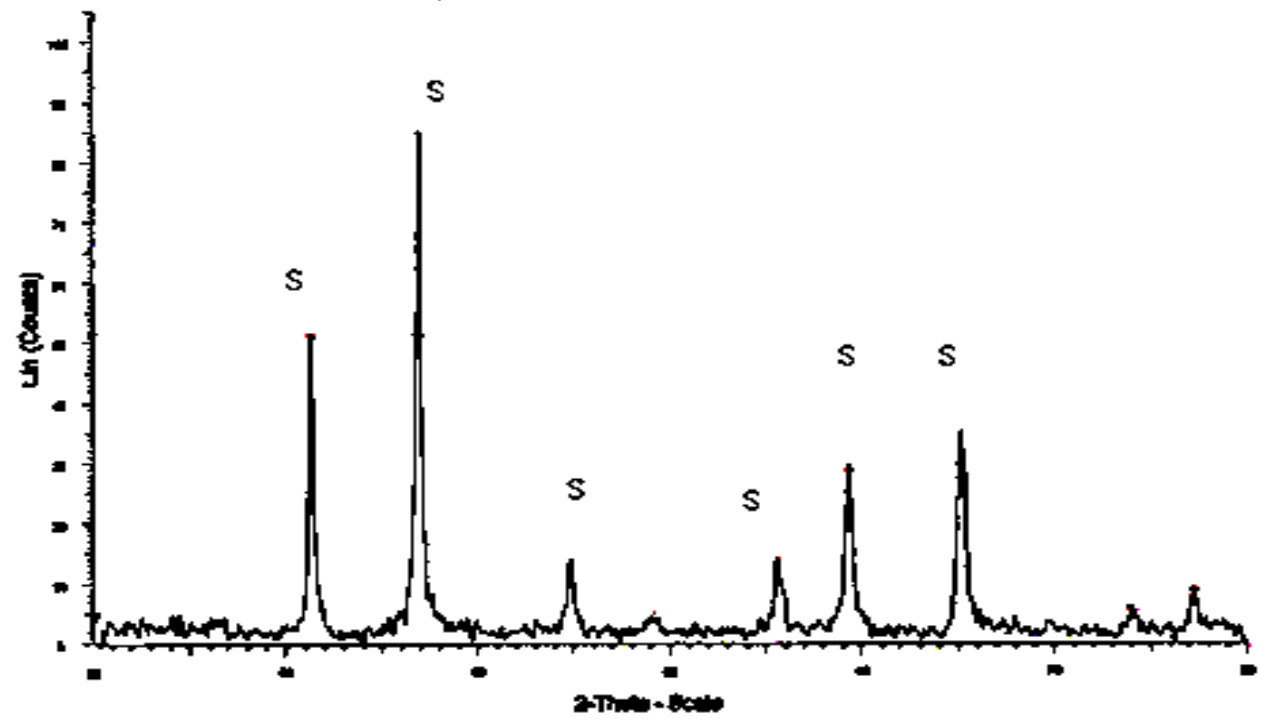

Fig. 1: XRD patterns of $\mathrm{Co}_{3} \mathrm{O}_{4}$ and $\mathrm{CoAl}_{2} \mathrm{O}_{4}$ mixture prepared by ceramic method $2 \mathrm{hrs}$. at $1000^{\circ} \mathrm{C}$. S, spinel.

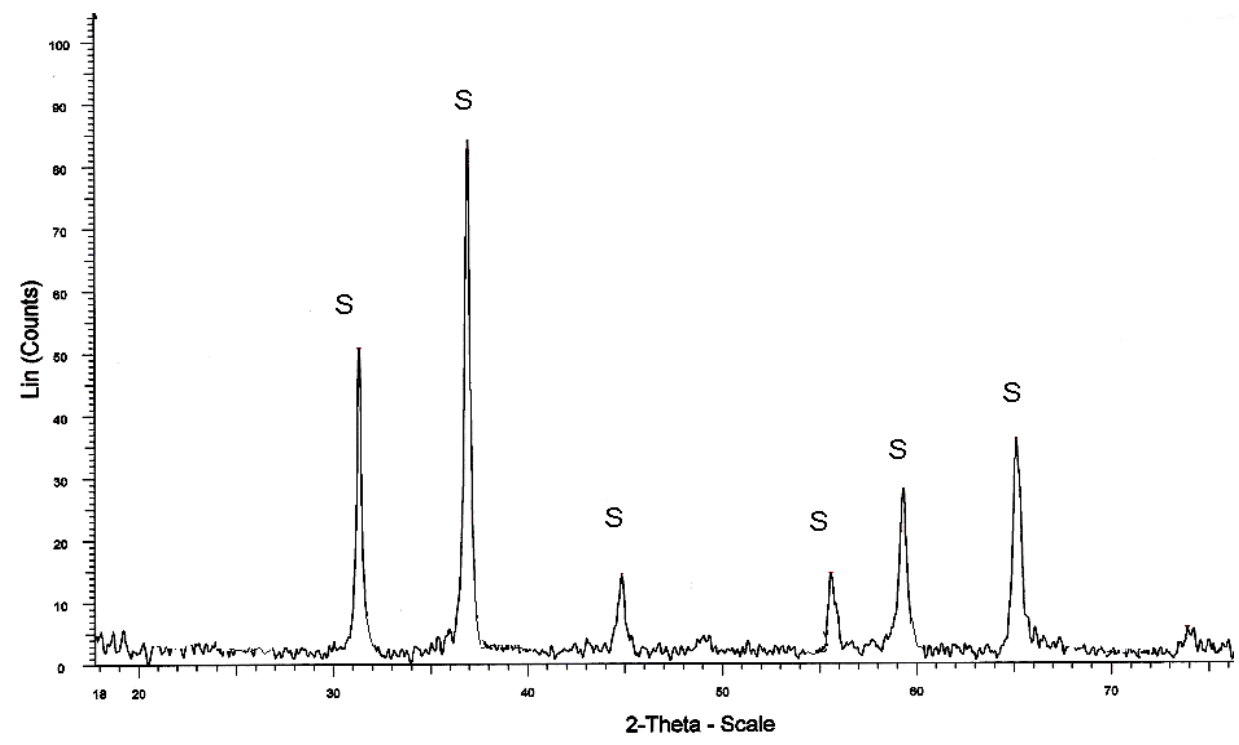

Fig. 2: XRD patterns of $\mathrm{CoAl}_{2} \mathrm{O}_{4}$ prepared by ceramic method 3hrs. at $1000^{\circ} \mathrm{C}$. S, spinel.

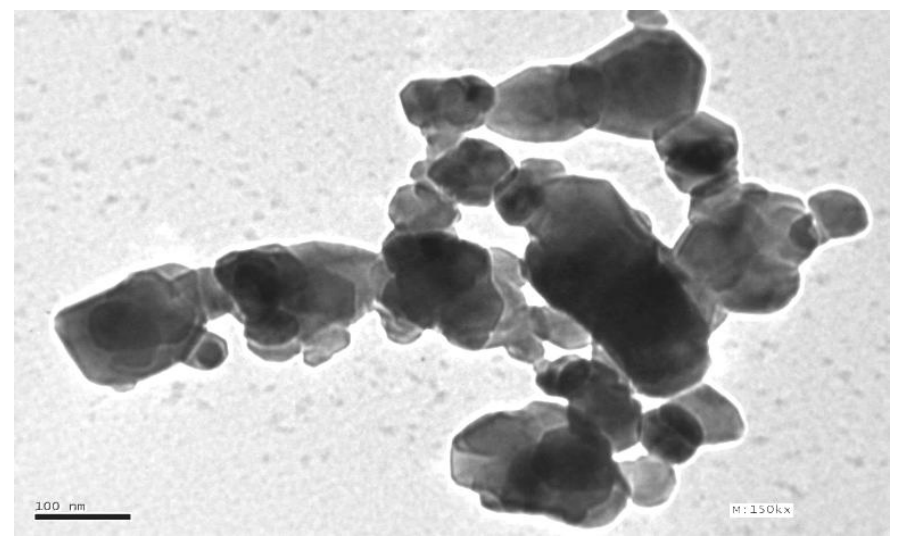

Fig. 3: TEM for 2 hrs. reaction is needed. It will give mixture of the $\mathrm{CO}_{3} \mathrm{O}_{4}$ and $\mathrm{Al}_{2} \mathrm{O}_{3}$ as suggested. 


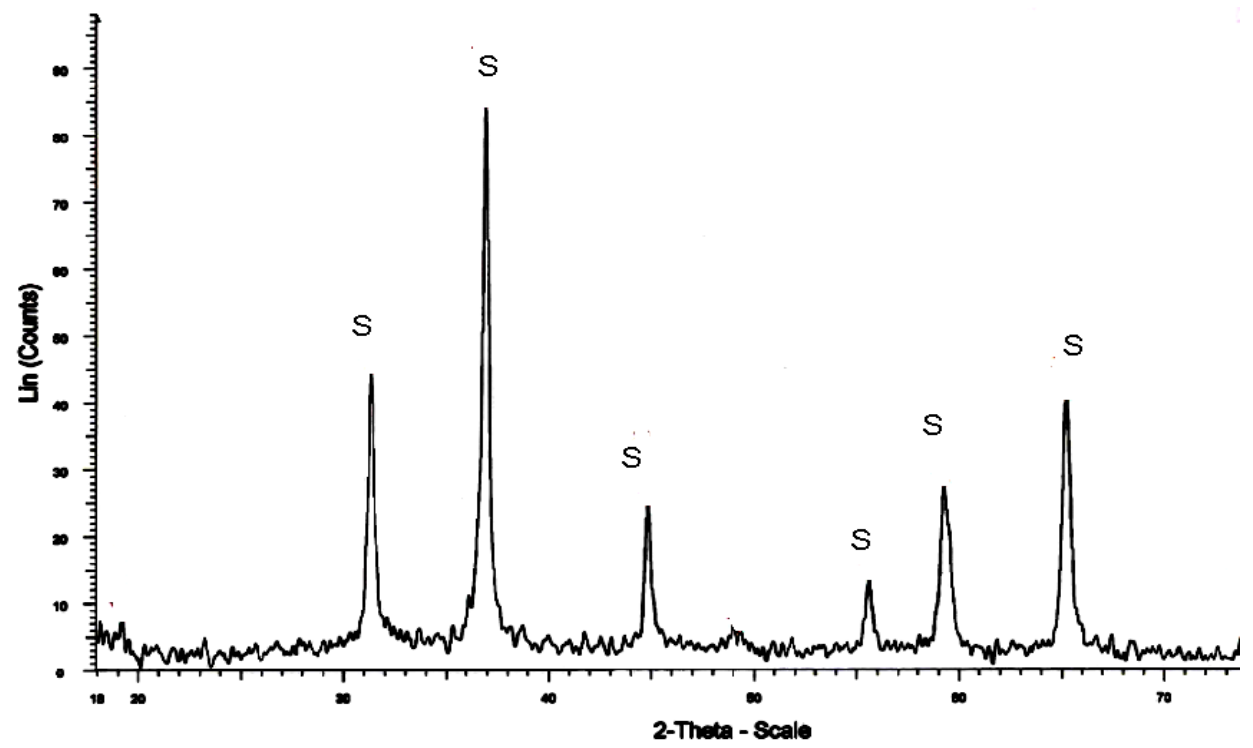

Fig. 4: XRD pattern of thermal product of $\mathrm{Co}\left(\mathrm{NO}_{3}\right)_{2}, \mathrm{MgCl}_{2}$ and $\mathrm{AlCl}_{3}$ using ceramic method $3 \mathrm{hrs}$ at $1000^{\circ} \mathrm{C}$ in molar ratio $0.75 \mathrm{Co}$ : $0.25 \mathrm{Mg}: 2 \mathrm{Al}$, respectively. S, spinel.

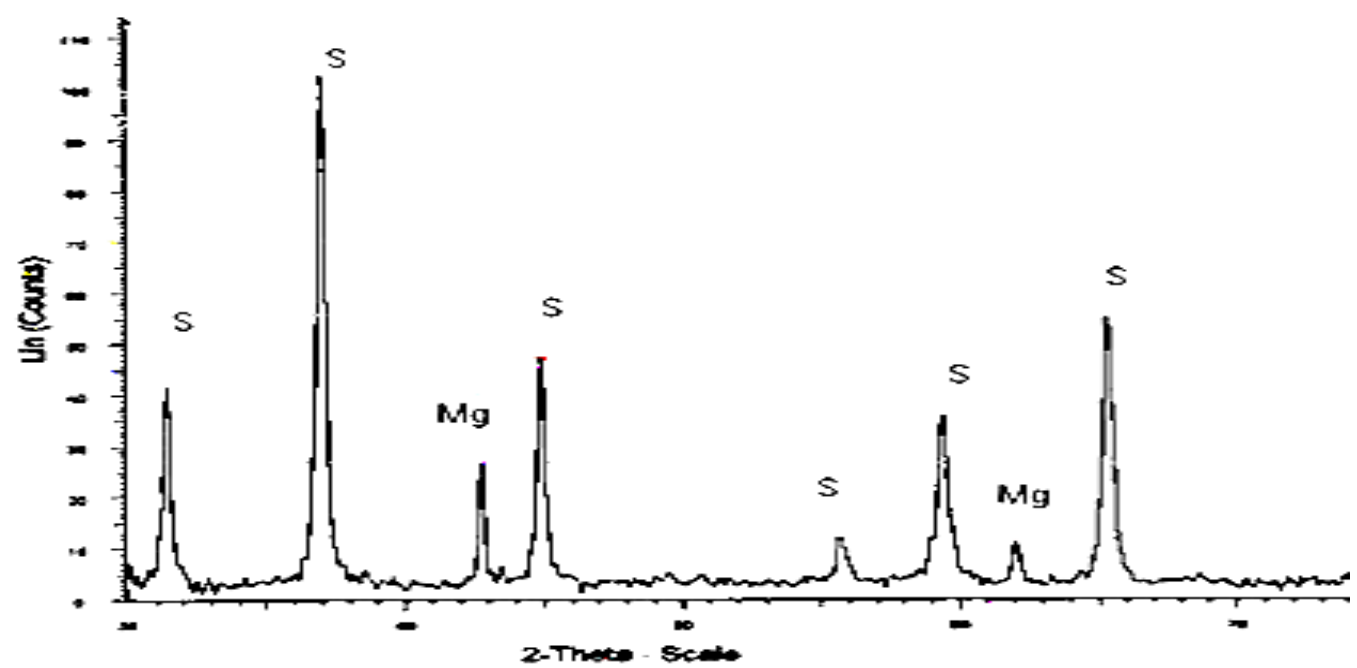

Fig. 5: XRD pattern of thermal product of $\mathrm{Co}\left(\mathrm{NO}_{3}\right)_{2}, \mathrm{MgCl}_{2}$ and $\mathrm{AlCl}_{3}$ using ceramic method $3 \mathrm{hrs}$. at $1000^{\circ} \mathrm{C}$ in molar ratio $0.5 \mathrm{Co}$ : $0.5 \mathrm{Mg}: 2 \mathrm{Al}$, respectively. S, spinel; $\mathrm{Mg}, \mathrm{MgO}$.

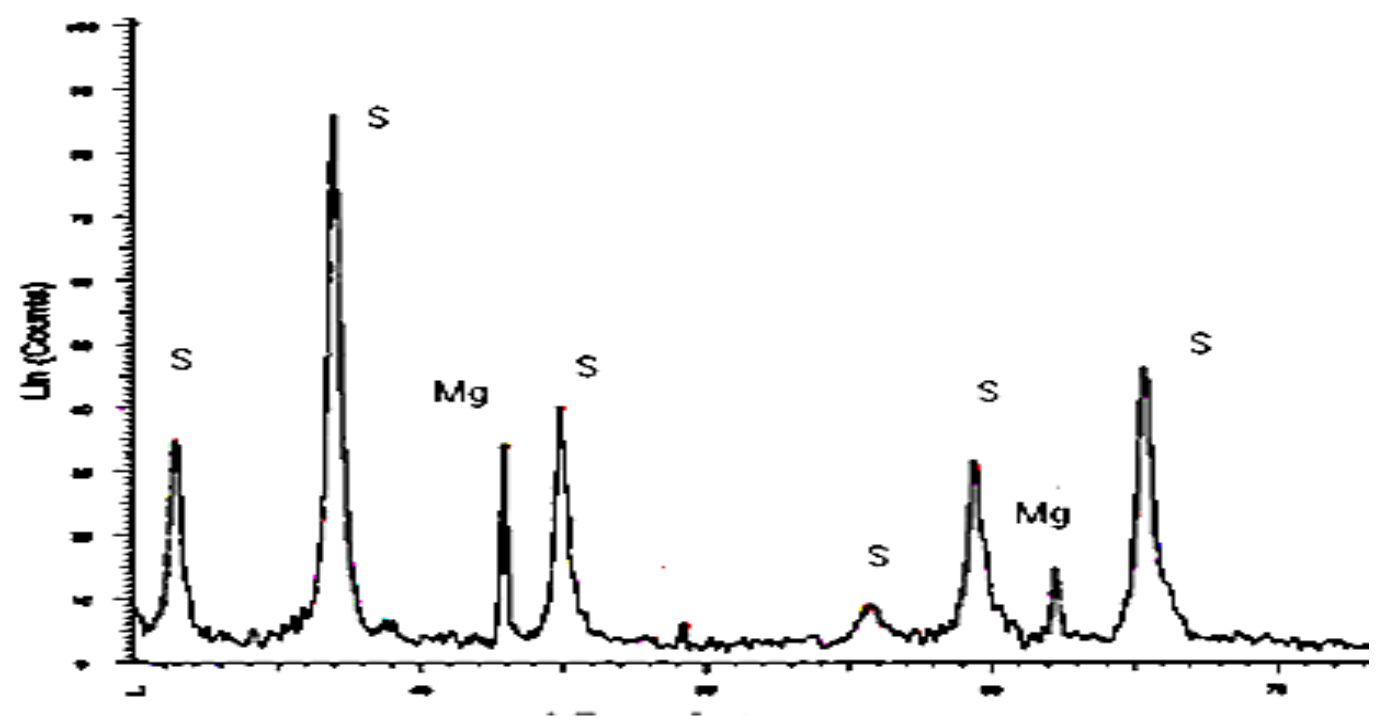

Fig. 6: XRD pattern of thermal product of $\mathrm{Co}\left(\mathrm{NO}_{3}\right)_{2}, \mathrm{MgCl}_{2}$ and $\mathrm{AlCl}_{3}$ using ceramic method $3 \mathrm{hrs}$. at $1000^{\circ} \mathrm{C}$ in molar ratio $0.25 \mathrm{Co}: 0.75 \mathrm{Mg}: 2 \mathrm{Al}$, respectively. S, spinel; $\mathrm{Mg}, \mathrm{MgO}$. 
From the above figures, it can be shown that the addition of small amount of $\mathrm{Mg}$ showed nearly the same XR-difractogram as the mixture without magnesium cf. Fig. 4 The increase of magnesium content up to 0.5 : 0.5 Co showed the appearance of the patterns of single $\mathrm{MgO}$ crystalline phase (Fig. 5). Further increase of magnesium leads to increase in the intensity of the patterns of the crystalline $\mathrm{MgO}$ phase.

The investigation of the formed spinel was studied by TEM. The micrographs obtained for these materials presents a detail of the composite. The TEM images of $\mathrm{Mg}_{\mathrm{x}} \quad \mathrm{Co}_{1-\mathrm{x}} \mathrm{Al}_{2} \mathrm{O}_{4} \quad \mathrm{x}=0.5$ or 0.75 demonstrates that the sample particle size is small and measured about 2050nm cf. Fig. 3 . The sample is a uniform distribution of spherical particles with no obvious aggregation. The increase of magnesium content showed a detectable decrease in size and more lightness of the particles.

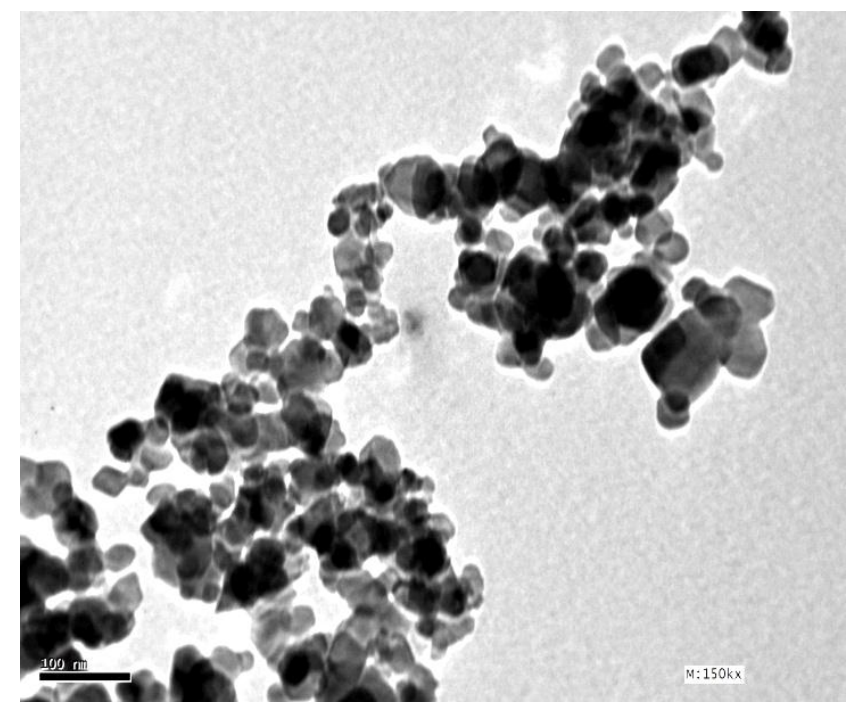

Fig. 7: TEM image of thermal product of $\mathrm{Co}\left(\mathrm{NO}_{3}\right)_{2}, \mathrm{MgCl}_{2}$ and $\mathrm{AlCl}_{3}$ using ceramic method $3 \mathrm{hrs}$. at $1000^{\circ} \mathrm{C}$ in molar ratio $(0.5 \mathrm{Co}: 0.5 \mathrm{Mg}: 2 \mathrm{Al})$ respectively.

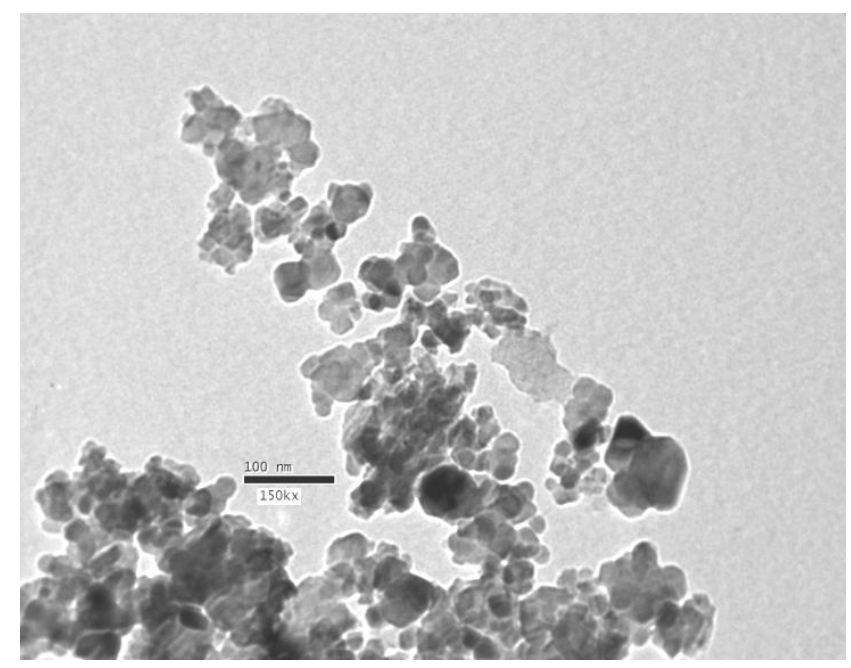

Fig. 8: TEM image of thermal product $\mathrm{Co}\left(\mathrm{NO}_{3}\right)_{2}, \mathrm{MgCl}_{2}$ and $\mathrm{AlCl}_{3}$ using ceramic method $3 \mathrm{hrs}$. at $1000^{\circ} \mathrm{C}$ in molar ratio $(0.25 \mathrm{Co}: 0.75 \mathrm{Mg}: 2 \mathrm{Al})$ respectively.
By using $\mathrm{CoAl}_{2} \mathrm{O}_{4}$ and $\mathrm{Co}_{\mathrm{x}} \mathrm{Mg}_{1-\mathrm{x}} \mathrm{Al}_{2} \mathrm{O}_{4}$ as pigments where it mixed with alkyd and covered the metallic surfaces, it exhibit good hiding to the surface because of they have the advantages of nano particles (Fig. 9).

\section{Conclusion}

In this paper, ceramic method was used to prepare nanometer $\mathrm{CoAl}_{2} \mathrm{O}_{4}$ and $\mathrm{Co}_{\mathrm{x}} \mathrm{Mg}_{1-\mathrm{x}} \mathrm{Al}_{2} \mathrm{O}_{4}$ pigment with spinel structure.

The crystallite size of the samples obtained using Scherrer equation $k \lambda=\mathfrak{t} \beta \cos \theta$ confirms that all samples are in the nano size in range $20 \mu \mathrm{m}$ to $40 \mu \mathrm{m}$.

The prepared pigments exhibit good hiding effect for the metallic surfaces when it applied as pigments for coating.
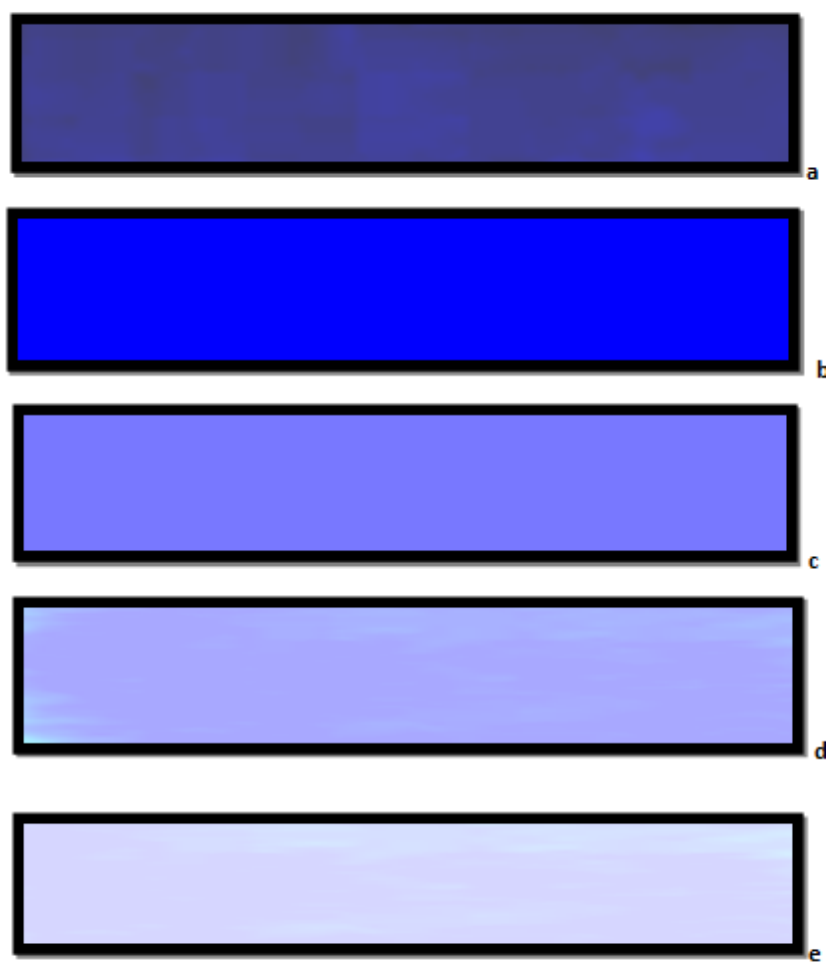

Fig. 9: The coated metallic surfaces with different colored pigments. a-CoAl $\mathrm{O}_{4}+\mathrm{Co}_{3} \mathrm{O}_{4}$, b- $-\mathrm{CoAl}_{2} \mathrm{O}_{4}, \quad$ c- $-\mathrm{Co}_{0.75} \mathrm{Mg}_{0.25} \mathrm{Al}_{2} \mathrm{O}_{4}, \mathrm{~d}-\mathrm{Co}_{0.5} \mathrm{Mg}_{0.5} \mathrm{Al}_{2} \mathrm{O}_{4}$, $\mathrm{e}-\mathrm{Co}_{0.25} \mathrm{Mg}_{0.75} \mathrm{Al}_{2} \mathrm{O}_{4}$

\section{References}

1) Yang B, Huang J.M., Hao E-C. (1997). The compositing and assembling of semiconductor nano particles in polymer matrix. Chemical Journal of Chinese Unive. 18: 1219.

2) Zhou Z, Yan J, Wang Y.X. (1998). Characteristics of nano crystalline material and its applications in electro Catalysis. Chemistry 4: 23.

3) Peter A.L. (1987). Pigment handbook. New york: John Wiley \& Sons.

4) Yang X.J., Liu E.S., Chen N.S. (1998). Preparation and gas-sensitivity of several spinel-type nano crystalline mixed oxides. Appl. Chem., 15(5):14.

5) Wang L.J., Zhang C.L., Li S. (1996). Studies on preparation and characterization of spinel ferrite. J. of Inorg. Chem., 12(4): 377. 
6) Zhenxing Y., Zhou J., Longtu, Honggno Z., Zhilun G., (2000). Synthesis of nano crystalline $\mathrm{NiCuZn}$ ferrite powders by sol-gel auto-combustion method. Journal of Magnet. and Mat., 208: 55.

7) Chen Y.J., Liu P.S., Jin Z.M. (1995). Studies of
$\mathrm{La}_{2} \mathrm{O}_{3}$ additive in Ni $\mathrm{Zn}$ ferrite. J. Mat. Sci. Lett., 14(14): 998.

8) Yang G.Q., Han B., Sun Z.T., Yan L.M., Wang X.Y., (2002). Preparation and characterization of brown nanometer pigment with spinel structure $\mathrm{J}$. of Dyes and Pigments. 55: 9. 